\title{
An Unfortunate Mistake or a Witkacy Dodge? ${ }^{1}$
}

\begin{abstract}
Degler Janusz, An Unfortunate Mistake or a Witkacy Dodge? [Przykra pomyłka czy szpryngiel Witkacego?] „Przestrzenie Teorii” 33. Poznań 2020, Adam Mickiewicz University Press, pp. 387-390. ISSN 1644-6763. DOI 10.14746/pt.2020.33.18.
\end{abstract}

In the Poetry of Philosophers anthology (Kraków-Wrocław 1984) Wit Jaworski published 221 works by 114 authors, starting with Tales from Milet to John Paul II. Almost all known philosophers composed poetry, which often complemented their philosophical reflections or concepts. The list of names also includes Stanisław Ignacy Witkiewicz, who wrote poems from his youth until his death, although at the same time regretting that he had no poetic talent and used some of his works in his dramas as examples of a graphomaniac's work. Many poems have a humorous and parodical, which brings them closer to his numerous grotesque drawings. They were collected and published by Anna Micińska in an album entitled Wistość tych rzeczy jest nie z świata tego (Kraków 1977), illustrated by Urszula Kenar. In the anthology, under the name of Witkiewicz, there is a poem which begins with words: "Otom jest zwyciężony/ Ginę zgubą wszelkiego żywego stworzenia". There is no doubt that this is the beginning of the third stanza of the well-known poem by Czesław Miłosz entitled St. Ign. Witkiewicz, published in the volume Ocalenie (Warsaw 1945). Is it an unfortunate mistake on the part of the author of the anthology, a seasoned critic and experienced editor, or is it his fortune to confuse the censor, who did not allow Miłosz's texts to be published and thus to "smuggle" his poem in under the guise of Witkiewicz? The puzzle remains unresolved. The mistake is inscribed in the history of Witkacy's so-called "dodges", which he did to his friends and acquaintances, and then to those who dealt with his life and work. To attribute to him the authorship of Miłosz's excellent work would certainly make him happy.

KEYWORDS: Wit Jaworski, poetry of philosophers, S.I. Witkiewicz's poetry, Czesław Miłosz

It is better to destroy one's own errors than those of others.

Democritus of Abdera

In August 1984, the Wydawnictwo Literackie Publishers published 3,283 copies of an anthology entitled Poetry of Philosophers [Poezja filozofów], carefully prepared by Wit Jaworski and preceded by his extensive dissertation Philosophers as Poets [Filozofowie jako poeci]. The volume contains poems by 119 authors, from Thales of Miletus to John Paul II. It transpires that almost all known philosophers composed poetry, which often complemented their philosophical reflections or concepts. There are the Pythagoreans and Protagoras, Aristotle and Cicero, Seneca and Diogenes, St. Augustine and Thomas

${ }^{1}$ Tekst w języku polskim: Janusz Degler, Przykra pomyłka czy szpryngiel Witkacego? został umieszczony na stronie internetowej <www.witkacologia.eu> (marzec 2020). 
Aquinas, Leonardo da Vinci and Giordano Bruno, Pascal and Voltaire, Novalis and Schlegel, Marx and Engels, Tatarkiewicz and Kotarbinski, Heidegger and Sartre. However, there are also those who are probably only known to philosophy historians, such as Pittacus of Mytilene, Philodemos of Gadara, the Venerable Bede, Peter Damian, John of Ruysbroeck or Jaime Balmes. The works of some of them may encourage us to discover their philosophical work, especially since the poems were translated by experienced translators, including W. Olszewski, B. Kupis, J. Dąmbska, W. Witwicki, T. Sinko, Z. Kubiak, L. Staff, L.R. Kołoniecki, T. Żeleński (Boy), A. Komorowski, J.S. Sito and Wit Jaworski. The majority of the philosophers were presented by one piece, but this is not the rule, because there some whom the anthologist endowed with several poems, such people Xenophanes of Colophon, Plato, Lucian of Samosata, Angelus Silesius, Hegel, von Schelling, de Unamuno and John Paul II. Ultimately, the anthology included 221 works, many of which were published for the first time in Polish.

Of course, Stanisław Ignacy Witkiewicz could not be absent from such an anthology. He openly admitted and regretted that he had no poetic talent, although writing poems had been his great passion since his youth. He introduced several works written at the time to plays written after 1918 (including $W$ matym dworku [In a small manor house] as examples of a graphomaniac's poetry). He often placed amusing verse on drawings, and inlayed letters to his wife with "bathing songs" composed during his morning ablutions, and to doctors he had befriended, as well as all those who let him down or offended him in some way, he sent the "narrative poems" To Doctor Friends and To Brat Friends. A large part of this poetic output was collected by Anna Micińska in her album entitled Wistość tych rzeczy jest nie z świata tego. Stanisława Ignacego Witkiewicza wiersze i rysunki (The viousness of these things is not of this world. Stanistaw Ignacy Witkiewicz-poems and drawings). The album was published jointly with Urszula Kenar (Cracow 1977; 2nd edition: Cracow 1984). They provided the basis for several theatre and television productions, and the song Hop, a glass of beer performed by Marek Grechuta became a hit at the Opole festival.

We open the volume at page 404. Under the name Stanisław Ignacy Witkiewicz (Witkacy) we see a poem under three stars:

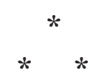

Otom jest zwyciężony,

Ginę zgubą wszelkiego żywego stworzenia.

A jednak wiem, że to mój, niczyj więcej los

Otom jest zwyciężony, odbiega mnie ziemia,

A kruchy kształt pamięci topi się jak wosk. 
Wszystkie stukoty kołysek, matek śpiewy, gdy dzieci kołysza,

Wszystkie dyszenia kochanków z oczami nabiegłymi krwia,

Wszystkie śniegi pomarańczowych górskich świtów

Mam jeszcze w sobie. Jeszcze chwilę - są.

Zanim upadnę w otchłań czarnego zenitu.

Oto zwycięża ludzkość, zacięta i płodna,

Która nie pragnąc tajemnicy mnoży się i trwa.

Ja, wbrew jej woli, chciałem sięgnać do dna

Chociaż ona ma słuszność - bo tak tylko

Dosięga się dna.

We rub our eyes in surprise... for that's not Witkacy but Czesław Miłosz! And the three best-known stanzas of the poem St. Ign. Witkiewicz from the volume Rescue, published in 1945. There is no work in Polish literature that expresses the motifs and sense of Witkiewicz's suicide so profoundly and poignantly.

What happened? Is it possible that Wit Jaworski, a seasoned literary critic and experienced editor ${ }^{2}$, could have made such an unfortunate mistake? It's hard to believe. Or was it a kind of examination for readers to check their knowledge of important texts in our post-war literature? Reviewers of the anthology ignored it and to this day the mystery remains unexplained. If the volume had been published before Miłosz was awarded the Nobel Prize in 1980, we might have suspected that Jaworski had set a trap for... the censor. We should remember, however, that from his decision 1 February 1951 to remain in exile, Czesław Miłosz had been considered one of the greatest enemies of the People's Republic of Poland, and was included on the censor's list of absolutely forbidden authors. Not only was it permitted to print his texts, but his name was erased and any quotations or references to specific works removed. The censors didn't allow themselves to be duped wording like "as the author of "The Captive Mind writes" or "let us recall the words of the author of "The Land of Ulro" etc., which in many cases forced authors to make significant changes to their

${ }^{2}$ J a w o r ski Witold Wit (born 1944) - poet, publicist, literary critic, historian of philosophy. Graduated from the Faculty of Philosophy at the Jagiellonian University; received his PhD in 1974 with dissertation Social Philosophy of Vincent Lutosławski. In 1981 became head of the Department of Philosophy at the AGH University of Science and Technology in Krakow. 1968 was the year of his poetic debut with poems published in "Student" magazine. Co-founder of the literary group "Teraz" [Now]. In the years 1983-1989 editor of the "Pismo Literacko-Artystyczne" [Literature and Art Magazine] monthly, and from 1990 editor-in-chief of the philosophical-artistic quarterly "Koniec Wieku" [End of the Century]. Published eleven volumes of poetry, a volume of short stories entitled Wielki ucisk [Great pressure] (1980), and a novel entitled Krótki lont [Short fuse] (1985). Publications include Buddhism. A Reader (together with J. Sieradzan and M. Dziwisz), Taoism. A Reader (M. Dziwisz ed.), Judaism. A Reader (together with A. Komorowski), Chinese fairy tales (1991). 
texts. So, did Jaworski, who had probably worked on the anthology for several years, decide to mock the censor and "smuggle" Miłosz's work in under the name of Stanisław Ignacy Witkiewicz? A risky hypothesis, but a possible one, given that after the imposition of martial law, problems with the printing of the anthology may have arisen (it was sent for typesetting on 5 May 1983). These were not, however, problems with censorship, because the restrictions on Miłosz were significantly eased after his being awarded the Nobel Prize. Both official publishers and samizdat authors tried to make up for this by publishing their poetry selections. The censor of the Poetry of Philosophers, hidden under the code name R-12-85, did not object to the presence in the volume of Miłosz's translations of the poem Krzyz by Simone Weil and Thomas Merton's Elegia for Ernest Hemingway. Even if he recognised who the author was of the work attributed to Witkiewicz, he had no reason to interfere. Jaworski, on the other hand, either forgot about his fortune or, fearing for the composition of the volume, did not wish to make any major changes.

Regardless of these or other reasons, this is yet another Witkacy 'dodge' sprung on those who deal with his life and work. It is clear that he liked theatrical dressing-up, imitated famous people perfectly and took on various characters: Napoleon, Mayakovsky, the Monster of Düsseldorf, Uncle from California, etc. He would surely have accepted with undisguised satisfaction the authorship attributed to him of Czesław Miłosz's excellent poem and considered this his most successful 'dodge'.

Janusz Degler

20 March 2020 - the fifth day of family-imposed lockdown

Translated by Rob Pagett

\section{BIBLIOGRAPHY}

Jaworski W., Poezja filozofów, Kraków-Wrocław 1984.

Micińska A., Witkacy - poeta, [in:] eadem, Istnienie Poszczególne: Stanisław Ignacy Witkiewicz, oprac. J. Degler, Wrocław 2003, p. 254-267.

Miłosz C., St. Ign. Witkiewicz, [in:] idem, Ocalenie, Warszawa 1945; reprint [in:] idem,

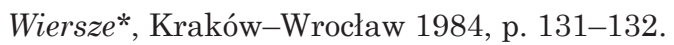

Wistość tych rzeczy jest nie z świata tego. Stanisława Ignacego Witkiewicza wiersze i rysunki. Wybrały i do druku podały A. Micińska i U. Kenar, Kraków 1977 (2nd ed. Kraków 1984).

Witkiewicz S.I., Dzieła zebrane, [vol. 23:] Varia, oprac. J. Degler, Warszawa 2019. 
